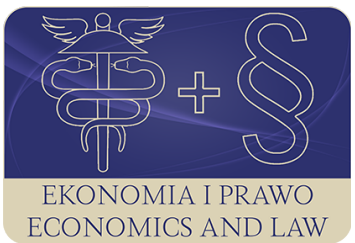

EKONOMIA I PRAWO. ECONOMICS AND LAW

Volume 20, Issue 2, June 2021

p-ISSN 1898-2255, e-ISSN 2392-1625

www.economicsandlaw.pl

EKONOMIA I PRAWO
ECONOMICS AND LAW

ORIGINAL ARTICLE

received 30.03.2021; revised 20.06.2021; accepted 30.06.2021

Citation: Wantoch-Rekowski, J., \& Cilak, M. (2021). The share of corporate income tax as revenue of a provincial self-government and the effects of the COVID-19 pandemic. Ekonomia i Prawo.

Economics and Law, 20(2), 439-456. https://doi.org/10.12775/EiP.2021.027.

\title{
The share of corporate income tax as revenue of a provincial self-government and the effects of the COVID-19 pandemic
}

\author{
JACEK WANTOCH-REKOWSKI \\ corresponding author \\ Nicolaus Copernicus University in Torun, Faculty of Law and Administration, Department of Public \\ Finance Law, ul. Bojarskiego 3, 87-100 Toruń, Poland \\ ๑rekowski@umk.pl \\ orcid.org/0000-0002-1606-7790 \\ MAEGORZATA CILAK \\ Nicolaus Copernicus University in Toruń, Faculty of Law and Administration, Department of Public \\ Finance Law, Poland \\ $\square$ mcilak@umk.pl \\ (iD) orcid.org/0000-0003-1429-8429
}

\begin{abstract}
Motivation: The paper addresses the issue of shares in corporate income tax (CIT) as revenue for the budgets of provincial governments. A study of the formation of revenues from this source in relation to total revenues in 2019-2021 was carried out, resulting in the observation that amongst the provinces a wide disparity exists in terms of the importance of CIT shares as a source of revenue. In most provinces, the percentage ratios of the size of CIT shares planned for 2021 in the structure of total revenue decreased compared with 2019. The study made it possible to advance a thesis on the possible impact of the COVID-19 pandemic on the decline in provincial revenue from CIT shares, as well as to confirm views criticizing certain features of CIT shares, such as their lack

of stability or the lack of influence of provincial governments on the shaping of this source of revenue. Shares in CIT formally constitute the provinces' own revenue, but in practice they are funds transferred from the state budget. Income taxes in Poland are
\end{abstract}


the revenue of the state, which has an exclusive influence on the normative shape of these taxes and the implementation of the regulations concerning them. The province, as a beneficiary of the CIT share, has no influence on this income. In view of the fact that in some provinces CIT revenue as a share of total revenue exceeds $40 \%$, a problem arises in the event of a decrease in the revenue from this tax to the state budget, and consequently to the provincial budgets. The COVID-19 pandemic and the economic crisis caused by it result, inter alia, in a decrease in revenues from income taxes, which is reflected in provincial budgets.

Aim: The aim of the article is to determine whether and to what extent the COVID-19 pandemic affected the revenues of self-governing voivodships from CIT shares. The authors also indicated solutions aimed at mitigating the negative consequences for provinces of the drop in revenues from CIT shares.

Results: The research carried out on revenues to the budgets of provincial local governments from the CIT share indicates that in 2021, 11 out of 16 provinces will have a lower percentage share of this income in the structure of all their revenues when compared to 2019.

Keywords: local government finance; provincial revenue; corporate income tax; COVID-19 JEL: K34; H7l; H72

\section{Introduction}

The basic legal regulations concerning local self-government units stem from the provisions of the Constitution of the Republic of Poland (1997). Pursuant to Article 163 of the Constitution of the Republic of Poland (1997), local government performs public tasks not reserved by the Constitution or statutes to the organs of other public authorities. Although in the light of Article 164(1), the basic unit of local government is the commune, the functioning of other units of regional or local and regional government is regulated by statute.

While at the local level, the idea of self-governance is realised by communes and poviats, at the regional level it is implemented only by self-governing provinces.

Self-governing provinces in Poland are vested with ownership and other property rights. Pursuant to Article 167(1) of the Constitution of the Republic of Poland (1997), all local government units, including self-governing provinces, are guaranteed a share in public revenue in accordance with the tasks allocated to them. Revenues are essential for the performance of tasks by local self-government units.

In the light of Article 167(2) of the Constitution of the Republic of Poland (1997) the revenues of local government units are their own revenues as are general subventions and earmarked subsidies from the state budget. Undoubtedly, their own revenues should play the main role in the structure of self-governmental revenues, while the funds transferred from the state budget (general subvention and earmarked subsidies) are to be their supplement.

Pursuant to Article 167(3) of the Constitution of the Republic of Poland (1997), the sources of income of local government units are specified by statute. Cur- 
rently, it is the Act on income of local government units (2003). A catalogue of their own revenues of provinces is set out in Article 6 of this Act. However, the catalogue does not include the most effective sources, i.e. taxes and fees. The revenues listed in Article 6(1) have no tangible financial significance in the structure of provincial revenues.

However, the thesis that local governments' own revenues are insignificant in the structure of provincial revenues would not be justified at the normative level, since the legislator, in Article 3(2), indicated that within the meaning of the Act, local government units' own revenues include shares in revenues from personal income tax and corporate income tax (CIT). Thus, the legislature qualified the funds transferred from the state budget as local governments' own income. However, this is an artificial procedure, because local government units have no influence on the shape and functioning of income taxes. The level of the share in the income tax on natural persons from the taxpayers residing in the area of the province is $1.60 \%$, while the level of the share in the income tax on legal persons residing in the area of the province is $14.75 \%$. There is no doubt that the provincial share in the corporate income tax is a very important income of this local government unit.

The reliance of local governments' own revenues on shares in income taxes may cause potentially serious problems for the provincial self-governments. First of all, it should be noted that any changes in the Corporate income tax act are made by the legislator, without the consent of the provincial self-government. Moreover, if, for instance, the Council of Ministers decides that it is beneficial to introduce tax reliefs or exemptions (on account of economic benefits), the financial consequences will also affect the local government unit.

In 2020, virtually the entire world was affected by the COVID-19 pandemic. In addition to the health sphere, the economic domain also suffered severe losses. It is reasonable to argue that most entrepreneurs recorded worse financial results in 2020 than in 2019, which was the last ,normal' year. Also the year 2021 should be considered less favourable than 2019. The consequence of the deterioration of the financial situation of entrepreneurs is a decrease in state budget revenues from corporate income tax. Owing to the fact that the provincial self-government bases part of its own revenues on the share in this tax, it can be assumed that the majority of provinces in 2020 and 2021 will generate less revenue.

The aim of the study is to verify the thesis that the COVID-19 pandemic has negatively affected the revenues of local government provinces from the share in corporate income tax in 2020-2021.

\section{Methods}

The article is based on an analysis of the texts of legal acts, mainly the Constitution of the Republic of Poland (1997) and laws, and so the choice of dogmatic-legal method is imperative. Furthermore, the article reviews and evaluates the Pol- 
ish literature concerning primarily the problems of income of local government units.

In order to verify the adopted thesis, it is necessary to analyse the data on revenues of all the provinces in 2019-2021 and also revenues from shares in corporate income tax. Individual amounts of total revenue and revenue from CIT shares for 2019-2020 were determined on the basis of resolutions of provincial boards on reports on budget implementation for 2019 and 2020, available on the public information bulletin (BIP) websites of individual provinces. Where it was not possible to obtain board resolutions, data were taken from the resolutions of the regional assemblies approving the reports of the boards or the reporting documents published on the BIP websites of the local governments. The amounts of total revenues and revenues from CIT shares planned as at 31 December of the budget year covered by the report were taken into account. In turn, for the year 2021, data were adopted on the basis of budget resolutions of provincial assemblies and resolutions on budget amendments and resolutions on changes in the budgets of individual provinces, published in the provincial official journals or in the BIP of individual provinces as of 27 April 2021.

\section{Literature review}

Local government shares in tax revenues constituting state budget income are the subject of research in both legal-financial and economic literature.

The legal-financial literature has devoted monographs, chapters in monographs, scientific articles, and other studies to the topic of shares. Among numerous authors who have taken up the issue of the tax shares it is necessary to mention Borodo (1991; 1993; 1995; 1997; 2012, 2020), Gilowska (1997), Gonet (2008; 2012), Miemiec (1996), Ofiarski (2010), Pest (2016), Ruśkowski \& Salachna $(2003 ; 2005)$ and many others. The subject of the research was the legal character of tax shares and their place in the structure of income of municipalities, the legal construction of the shares, the advantages and disadvantages of using this type of source of income of municipalities, as well as other issues, such as those related to the judicial recovery of tax share debts by the local government units.

In the economic literature, the problem of the revenue system of self-government units and tax shares has been studied by, inter alia, Dziemianowicz (2017), Guziejewska (2004; 2014; 2016), Kańduła (2016; 2017), Neneman \& Swianiewicz (2014), Poniatowicz (2012; 2015), Surówka (1997; 2007) and others.

Representatives of the financial law academia are unanimous in their view that shares in state taxes cannot be treated as the local government's own revenue, as they recognise that their own revenue is generated by sources which can be influenced, to a certain extent, by the local government. Thus, revenue from fiscal shares may - at most - be regarded as revenue, equivalent to local governments' own revenue', and not their own revenue sensu stricto (see, inter alia, Gonet, 2008, pp. 25-27; Ruśkowski \& Salachna, 2003 p. 57; 2005, p. 104). 
Basing the system of revenues of local government units on tax shares cannot be regarded as corresponding to the essence of self-governance of local government units. They are a type of subsidy or subvention, and not the local governments' own revenue (Małecki 1991, p. 40). Shares in taxes constituted the revenue of local government units as far back as the inter-war period. The system of revenues of local government units from that period was examined by, amongst others, Borodo (1993, pp. 48-67). Tax shares were also utilised after World War II. As indicated by Ruśkowski \& Salachna (2003, pp. 13-17; 2005, p. 104) in their commentaries to the Act on income of self-government units in 1999-2003 and the currently binding Act on income of self-government units, they were an element of the system of income of national councils in the People's Republic of Poland.

After the political transformation of 1989 and the restoration of local government in Poland, various authors have made numerous proposals concerning the shape of the local government revenue system and the role of local government shares in state taxes in that system (e.g. Borodo 1991; 1995; 1997, pp. 39-41; Miemiec, 1996, pp. 18-20). It was postulated that the system of sources of revenue of the local government should be based on its own revenue. It was also seen as including shares in state taxes, not only - as finally decided by the legislator - in income taxes, but also in indirect taxes (Borodo, 2020; Gilowska, 1997, pp. 20-21; Gilowska et al., 1997, pp. 39 et seq., 44 in., 94 et seq.; Gonet, 2012, pp. 18-20), as well as supplements to state taxes and transfer revenue, such as subsidies and grants from the state budget.

The legal construction of tax shares and their significance for local governments was the subject of Borodo's research. He pointed out the existence of several modes of distributing tax revenue between the state and local government: a system of tax competition, a system of tax allowances, a system of tax shares, a system of separation of sources of revenue, and mixed systems. He indicated that the shares could have a different legal structure, and relate to tax revenues collected in the territory of a given local authority, or be detached from them. As the main advantages of the system of percentage or fractional shares, he pointed out the absence of excessive burdening of tax revenue sources by the public sector. The same tax burden throughout the country makes it possible to pursue a uniform tax policy. The disadvantage, on the other hand, is the limitation of the tax independence of local self-governments if they do not have their own sources of tax revenue that they can shape. Another disadvantage may be disputes between local authorities over the amount of shares - each community seeks to ,win' the largest possible percentage share for itself (Borodo, 1993, pp. 22-30). He considered the tax shares as the equivalent of the ,municipal income tax' and as a properly selected income of the local authority, linking the income of the taxpayers to the income of the local authority where they are domiciled (Borodo, 1995, p. 31 et seq.).

Kornberger-Sokołowska \& Bitner (2018, pp. 92-93) treat the shares of local authorities in state taxes as a form of systemic redistribution of income collected 
centrally. Apart from their strictly fiscal function, the said shares also stimulate local governments to pursue appropriate local policies. When introducing these regulations, the legislator aimed to activate the impact of local governments on the economic and social development of their areas within the scope of their competence. At the same time, however, it is possible to pursue a nationally uniform tax policy.

Dębowska-Romanowska (1996, p. 324; 2000, p. 168) pointed out that the term ,shares in state taxes' in the light of the provisions of the Act on the income of self-government units means shares in revenues from taxes constituting the income of the state budget, and not shares in taxes themselves. This means that their transfer is not of an indefinite nature, but has its effect as per the legal status applicable in the financial year. At the end of the year - in the event of a change in the legal status - the right to collect receivables from the share in tax revenues settled after the end of the financial year expires. As regards determining the receivables of local authorities on account of shares, the principle of annuality applies.

A detailed analysis of the tax shares of local government units has been carried out by Pest (2016, pp. 37-44). He has pointed out that the institution of tax shares is an element of budgetary law, not substantive tax law. The Act on the income of local government units (2003), which regulates the institution of shares, is not a tax act. Moreover, the Tax ordinance act does not apply to tax shares. As a result, the tax share is not a tax, fee or non-tax budgetary receivable.

Shares in income tax from natural persons following the political transformation in Poland were also the subject of research conducted by Ofiarski (2010, p. 290), who presented an analysis of the legal status, the evolution of the legal construction of shares and their functioning in the years 1990-2010.

Various authors have also pointed out the drawbacks of shares in the form of dependence of revenues from this source on the economic situation, which means that they are not the most stable source of revenue for local self-governments (e.g. Ofiarski, 2010, p. 295). The amount of revenue from tax shares is also impacted by the implementation of tax reliefs by the state tax authorities in the repayment of tax liabilities in income taxes (Dębowska-Romanowska, 2000, p. 168).

Some authors point out that tax shares do not perform motivational functions for local self-governments because of the lack of competence of the latter to shape these sources of revenue. Nevertheless, the share structure is beneficial for local government units where the residence of a personal income tax payer or the seat or establishment (branch) of a corporate income tax payer is located. Therefore, local governments may take various legally permissible measures to increase the interest of taxpayers in residing or establishing offices in the territory of local government units, as this translates into higher revenues from tax shares (Borodo, 2012, pp. 89, 97, 131-133, 144-145; Gonet, 2008, p. 27).

The judicial route for claiming the proceeds from tax shares has also been the subject of interest in financial law doctrine. Agopszowicz \& Gilowska (1999, 
p. 391) indicate that the revenues from tax shares do not have a civil law character, and therefore the local authority may not pursue the payment of the amount of money by the State Treasury on account of these shares through a court decision. A different view was expressed by Borodo (2012, pp. 92-93).

In economic literature, the issue of local government shares in state taxes is also an object of interest. Dziemianowicz (2017, p. 93 et seq.) has analysed their structure and influence on the autonomy of local government units in terms of revenue, concluding that revenue from this source is of great fiscal importance for local government units. Income from a share in corporate income tax is more susceptible to these fluctuations than income tax from natural persons. In addition, the amount of tax revenues of local self-government units and thus their financial independence - is influenced by the unilateral decisions of the legislators introducing tax reliefs, the economic effect of which is borne by the local government units, while the state authorities can compensate for the loss of revenue by increasing revenue from other sources (Dziemianowicz \& Wyszkowski, 2012, pp. 166 et seq.).

According to Surówka (2007, p. 197; see also 1997, p. 21 et seq.), percentage shares in income taxes are a kind of subsidy, conditional on the economic situation, which was offered to local governments after 2003, instead of a subsidy guaranteed by law. In Surówka's opinion, the increase of revenues of local self-governments by raising the percentage shares in central taxes is only an ostensible gain of independence for local self-governments in Poland. The shares can be attributed to the nature of a part of the equalisation mechanism, and not typical local governments' own revenues of self-government units (Peter-Bombik, 2009, p. 346). In the view of Surówka \& Winiarz (2011, p. 356), the system of tax shares should ultimately be replaced by a system of additions to state taxes, in order to increase the revenue independence of local government units.

The system of income of self-government units and effectiveness of local taxes was also studied by Guziejewska (e.g. 2004; 2014; 2016) and Żołądkiewicz (2014). The topic of tax shares was also addressed by Kańduła (e.g. 2017) and Poniatowicz (e.g. 2012; 2015; Poniatowicz \& Dziemianowicz, 2016).

Representatives of the economic sciences have also formulated the concept of municipal PIT. The general assumption of this idea is to maintain the division of personal income tax revenue between the state and the local government, with the latter being granted the competence to shape this source of revenue within a specified scope (Kańduła, 2016; Neneman \& Swianiewicz, 2014).

In conclusion, it should be stressed that representatives of the legal and economic sciences agree on the most important issues related to tax shares of local self-governments. In their opinion, these are transfer revenues, constituting a type of subsidy or grant, which do not provide local self-governments with sufficient financial independence. They also notice cyclical fluctuations of revenues from these sources, with changes in revenues from PIT share being im- 
pacted by other factors (mainly changes in this tax introduced by the legislator) as compared to revenues from CIT share (changes in the economic situation).

\section{Discussion of results}

Table 1 contains data on total revenues and CIT revenues of all Polish self-governing provinces (16) for the years 2019-2021. The data for the years 20192020 concern realized (accomplished, actual) revenues and for the year 2021 they are forecasts, in the sense that they represent projections resulting from budget resolutions. Long-term observations indicate that budget resolutions are repeatedly amended during the year, therefore it may be expected that the data for 2021 will be subject to changes as well. Table 1 also contains results regarding the percentage share of each province's CIT revenues in total revenues. It also indicates how this share changed in 2021 in relation to 2019 (the base year).

The COVID-19 pandemic, whose effects affected Poland as well, had and continues to have effects in the economic sphere. Although it is evident that for most economic entities the pandemic was a negative or, alternatively, neutral factor, it should not be forgotten that for some entities (certainly fewer) it was beneficial (e.g. manufacturers of protective masks, protective gloves, or disinfectant fluids). From the perspective of the activity of entrepreneurs and profitability of this activity, it may be expected that income of the majority of corporate income tax payers will be lower in the years affected by the pandemic compared to earlier years.

Considering the share of CIT revenues in the total revenues in the base year, 16 provinces can be divided into several groups:

- Group I: provinces where the share of CIT in total revenue is greater than 40\%: Mazowieckie (69.86\%), Dolnośląskie (46.10\%), Wielkopolskie (43.84\%), and Śląskie (43.52\%);

- Group II: provinces in which the share of CIT in the total revenue is greater than 20\% and does not exceed 40\%: Pomorskie (36.29\%), Małopolskie (36.09\%), Łódzkie (31.36\%), Kujawsko-pomorskie (26.25\%), and Lubuskie (21.17\%);

- Group III: provinces where the share of CIT in the total income is lower than 20\%: Zachodniopomorskie (19.66\%), Opolskie (16.83\%), Podkarpackie (15.55\%), Lubelskie (13.25\%), Warmińsko-Mazurskie (13.17\%), Świętokrzyskie (12.66\%), and Podlaskie (9.26\%).

The noticeable considerable differences between the shares of CIT in total income between provinces from group I and group III result from the degree of economic development of particular provinces and the number of business entities generating income and paying personal income tax. Based on general common knowledge about the foundations of the Polish economy, it can be concluded that the Mazowieckie province is the most economically developed and the Podlaskie province the least developed. From the abovementioned data it clearly results that the financial economy of the Mazowieckie province is 
based on the revenue from the share in the corporate income tax (69.86\%), whereas for the Podlaskie province this revenue is of a supplementary, secondary nature $(9.26 \%)$.

The decrease in the share of CIT revenues in total revenues in 2021, as expected by the authors compared to the base year 2019 (in \%), occurred in 11 of the 16 provinces. In the remaining (5) an increase was observed. However, this increase did not occur in any province classified under group I. It was observed in two provinces from group II and in three provinces from group III.

Decreases in the share of CIT revenues in total revenues in individual provinces varied in size - from $11.62 \%$ in the Kujawsko-Pomorskie province to $0.55 \%$ in the Śląskie province. A lesser spread was observed in terms of growth - from 5.17\% (Podlaskie) to 0.23\% (Opolskie).

The survey conducted should be treated as preliminary. Data for 2020, which was the first year of the COVID-19 pandemic, reflect the effects of the crisis for an incomplete year - the Polish economy began to suffer perturbations from March 2020. Data for 2021, on the other hand, are forecasts, often made under the influence of optimistic information about the end of the pandemic, which has not happened and will not take place in the coming months.

\section{Conclusion}

As indicated in the literature review - representatives of the doctrine have for many years highlighted the weakness of the construction of revenue sources of local government units, including self-governing provinces. Assuming that shares in state income taxes are a province's own income is illusory. Provincial revenues from shares in personal income tax and corporate income tax are the classic funds transferred from the state budget. The provinces have no influence on this source of their own income. In fact, the formal qualification of funds transferred from the state budget does not change their nature, as they do not become, by law, their actual own revenues.

While it is known when most corporate taxpayers began to be affected by the pandemic, it is uncertain when this phenomenon will cease, assuming that it will. However, it cannot be ruled out that other events of a similar nature will occur, which will realistically affect economic entities. The analysis of revenues from CIT shares to the budgets of self-governing provinces shows that this income which is important for almost all provinces, is not stable. Owing to the fact that the tasks of self-governments, and consequently expenditures on the performance of these tasks, have an upward trend, it is not possible for provinces to function properly in a state of financial uncertainty. It is evident that in the area of classic local governments' own revenues (e.g. property tax being the revenue of the municipality), local government units have legal instruments which they can use to at least minimally influence the efficiency of a particular source of revenue. In the case of funds transferred from the state budget, local government units are not equipped with any legal instruments. 
In terms of the construction of local government shares in CIT, adjustments to the legal solutions are necessary as a minimum measure. Mechanisms should be adopted to correct provincial revenues in this respect, consisting in supplementing the shortfall in CIT revenues for a given province in relation to the previous year. It should be guaranteed that provinces' revenues from this source in each subsequent year will not be lower than in the previous year. This type of corrective mechanism would in no way affect the financial independence of a province. Instead, it would ensure that revenues from the CIT in the following year would not be lower, which would enable rational planning and implementation of the budget of a self-governing province.

\section{References}

Agopszowicz, A., \& Z. Gilowska, Z. (1999). Ustawa o gminnym samorządzie terytorialnym: komentarz. C.H. Beck.

Borodo, A. (1991). Obiektywizacja subwencji ogólnych dla gmin. Samorząd Terytorialny, 3, 16-31.

Borodo, A. (1993). Dochody samorządu terytorialnego w Polsce: studium finansowoprawne. Uniwersytet Mikołaja Kopernika w Toruniu.

Borodo, A. (1995). Udział gmin w podatku dochodowym od osób fizycznych: zagadnienia prawne. Samorzad Terytorialny, 11, 31-39.

Borodo, A. (1997). Wybrane zagadnienia dochodów samorządu powiatowego. Samorzad Terytorialny, 1-2, 35-44.

Borodo, A. (2012). Samorzad terytorialny: system prawnofinansowy. LexisNexis Polska.

Borodo, A. (2020). Niektóre problemy finansów samorządu terytorialnego w Polsce oraz propozycje nowych regulacji dotyczących dochodów samorządu. Finanse Komunalne, 2, 66-72.

Dębowska-Romanowska, T. (1996). Prawne zasady podziału dochodu pomiędzy państwo a samorząd terytorialny. In A. Piekara, \& Z. Niewiadomski (Ed.), Samorząd terytorialny i rozwój lokalny (pp. 317-330). Uniwersytet Warszawski. Centrum Studiów Samorządu Terytorialnego i Rozwoju Lokalnego.

Dębowska-Romanowska, T. (2000). Zasady podziału dochodów pomiędzy państwo a samorząd terytorialny. In B. Brzeziński, T. Dębowska-Romanowska, M. Kalinowski, \& W. Wójtowicz (Eds.), Prawo finansowe (3rd ed., pp. 147-181). C.H. Beck.

Dziemianowicz, R. (2017). Dysfunkcje udziałów w podatkach państwowych w aspekcie zmniejszającej się samodzielności dochodowej samorządu terytorialnego w Polsce. Prace Naukowe Uniwersytetu Ekonomicznego we Wroctawiu, 485, 90-107. https://doi.org/10.15611/pn.2017.485.08.

Dziemianowicz, R., \& Wyszkowski, A. (2012). Preferencje w podatkach lokalnych i ich wpływ na dochody JST. Annales Universitatis Mariae Curie-Sktodowska. Sectio H: Oeconomia, 46(3), 165-174. 
Gilowska, Z. (1997). Finanse województwa samorządowego. Samorząd Terytorialny, 3, 3-25.

Gilowska, Z., Płoskonka, J., Prutis, S., Stec, M., \& Wysocka, E. (1997). Model ustrojowy województwa (regionu) w unitarnym państwie demokratycznym: raport końcowy. Samorząd Terytorialny, 8-9, 3-140.

Gonet, W. (2008). Pojęcie dochodów własnych w jednostkach samorządu terytorialnego. Finanse Komunalne, 1-2, 23-29.

Gonet, W. (2012). Partycypacja samorządu terytorialnego w podatkach pośrednich jako źródło dochodów. Finanse Komunalne, 9, 17-23.

Guziejewska, B. (2004). Podstawowe założenia subwencji ogólnej dla jednostek samorządu terytorialnego w Polsce na tle konstrukcji teoretycznych. Samorzad Terytorialny, 11, 40-48.

Guziejewska, B. (2014). Polityka kształtowania dochodów samorządu terytorialnego w świetle wybranych koncepcji teoretycznych. Prace Naukowe Uniwersytetu Ekonomicznego we Wroctawiu, 326, 60-70.

Guziejewska, B. (2016). W poszukiwaniu efektywnego systemu podatków samorządowych. Annales Universitatis Mariae Curie-Sktodowska. Sectio H: Oeconomia, 50(1), 275-283.

Kańduła, S. (2016). PIT komunalny jako nowa forma dochodów jednostek samorządu terytorialnego. Infos, 16(220), 1-4.

Kańduła, S. (2017). W sprawie funkcji wyrównawczej udziałów jednostek samorządu terytorialnego w podatkach wspólnych. Prace Naukowe Uniwersytetu Ekonomicznego we Wroctawiu, 485, 218-229.

Konstytucja Rzeczypospolitej Polskiej z dnia 2 kwietnia 1997 r. [Constitution of the Republic of Poland of 2 April 1997] (Dz.U. 1997 nr 78 poz. 483) (Poland).

Kornberger-Sokołowska, E., \& Bitner, M. (2018). Prawofinansów samorządowych. Wolters Kluwer Polska.

Małecki, J. (1991)Finanse gminy samorządowej de lege lata i de lege ferenda. Ruch Prawniczy, Ekonomiczny i Socjologiczny, 53(2), 37-46.

Miemiec, W. (1996). Konsekwencje nowelizacji przepisów ustawy o finansowaniu gmin. Finanse Komunalne, 1, 18-27.

Neneman, J. \& Swianiewicz, P. (2014). Co PIT komunalny znaczy dla finansów samorządowych. Finanse Komunalne, 1-2, 80-91.

Ofiarski, Z. (2010). Udziały we wpływach z podatku dochodowego od osób fizycznych jako źródło dochodów samorządu terytorialnego w Polsce w latach 1990-2010. In Z. Ofiarski (Ed.), Wyższa Szkota Administracji Publicznej w Szczecinie 1995-2010: księga jubileuszowa (pp. 281-302). Wyższa Szkoła Administracji Publicznej w Szczecinie.

Pest, P. (2016). Udziaty jednostek samorządu terytorialnego we wptywach z podatków dochodowych. C.H. Beck. 
Peter-Bombik, K. (2009). Samodzielność finansowa jednostek samorządu terytorialnego w Polsce: założenia a rzeczywistość. In J. Parchomiuk, B. Ulijasz, \& E. Kruk (Eds.), Dziesięć lat reformy ustrojowej administracji publicznej w Polsce (pp. 340-352). Wolters Kluwer Polska.

Poniatowicz, M. (2012). Wpływ kryzysu gospodarczego na dochody największych miast z tytułu udziałów w podatkach państwowych. Zeszyty Naukowe Wyższej Szkoty Bankowej we Wroctawiu, 29, 127-138.

Poniatowicz, M. (2015). Determinanty autonomii dochodowej samorządu terytorialnego w Polsce. Nauki o Finansach. Financial Sciences, 1(22), 11-30.

Poniatowicz, M., \& Dziemianowicz, R. (2016). Udziały samorządu terytorialnego $\mathrm{w}$ państwowych podatkach dochodowych $\mathrm{w}$ aspekcie postulatów teoretycznych federalizmu fiskalnego. Annales Universitatis Mariae Curie-Sktodowska. Sectio H: Oeconomia, 50(1), 296-303. https://doi. org/10.17951/h.2016.50.1.295.

Ruśkowski, E., \& Salachna, J. (2003). Ustawa o dochodach jednostek samorządu terytorialnego w latach 1999-2003: komentarz. ABC.

Ruśkowski, E., \& Salachna, J. (2005). Ustawa o dochodach jednostek samorządu terytorialnego: komentarz. ABC.

Surówka, K. (1997). Koncepcje zasilania finansowego poszczególnych szczebli samorządu terytorialnego w Polsce. Samorząd Terytorialny, 12, 21-34.

Surówka, K. (2007). Dotacje a udziały w podatkach dochodowych jako źródła dochodów JST w Polsce. Zeszyty Naukowe Uniwersytetu Szczecińskiego. Problemy Zarządzania, Finansów i Marketingu, 451(11), 191-198.

Surówka, K., \& Winiarz, M. (2011). Wpływ podatków dochodowych na kondycję finansową samorządu terytorialnego w Polsce. Zeszyty Naukowe Wyższej Szkoty Bankowej we Wroctawiu, 21, 347-357.

Ustawa z dnia 13 listopada 2003 r. o dochodach jednostek samorządu terytorialnego [Act of 13 November 2003 on the income of local government units] (Dz.U. 2003 nr 203 poz. 1966) (Poland).

Żołądkiewicz, A. (2014). Samodzielność finansowa gmin w Polsce. Przedsiębiorczość i Zarządzanie, 15(10), 287-297.

\section{Acknowledgements}

Author contributions: authors have given an approval to the final version of the article. Authors contributed to this work as follows: J.W.-R. developed the concept and designed the study, M.C. collected the data, J.W.-R. and M.C. analysed and interpreted the data, J.W.-R. prepared the draft of the article, J.W.-R. and M.C. revised the article critically for important intellectual content.

Funding: this research was fully funded by the Nicolaus Copernicus University in Torun, Faculty of Law and Administration. 


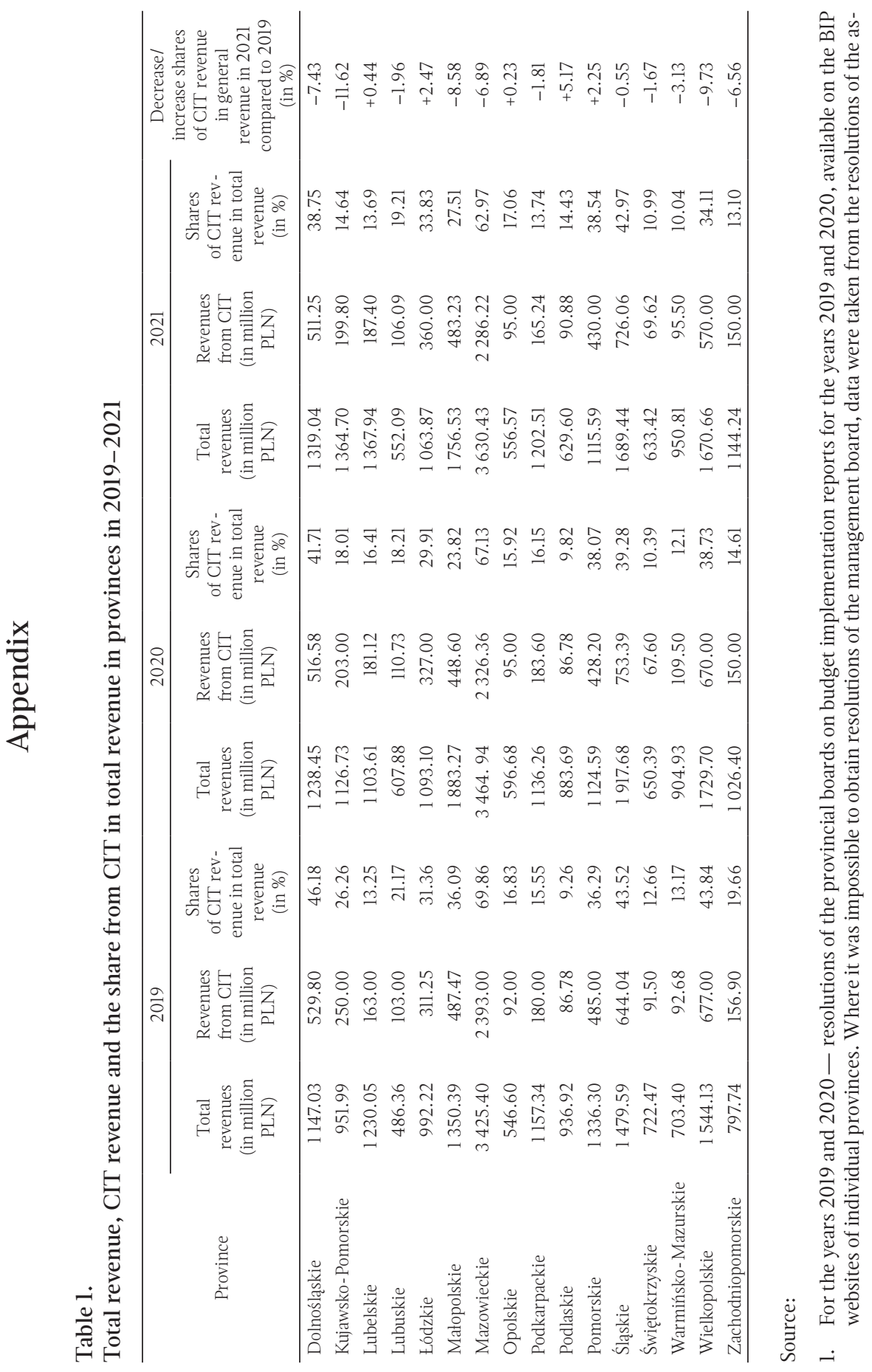




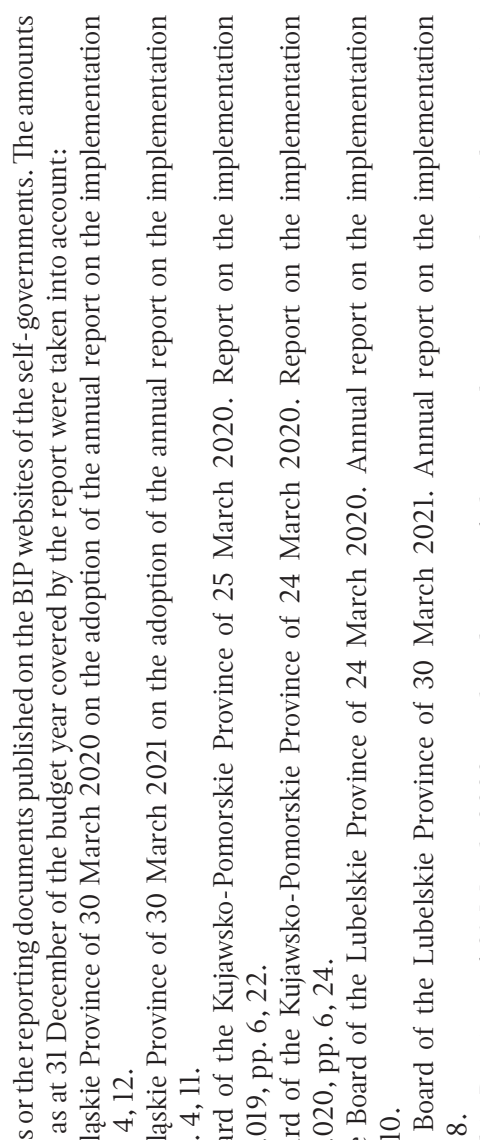

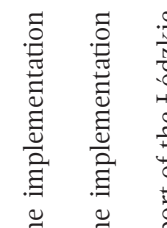

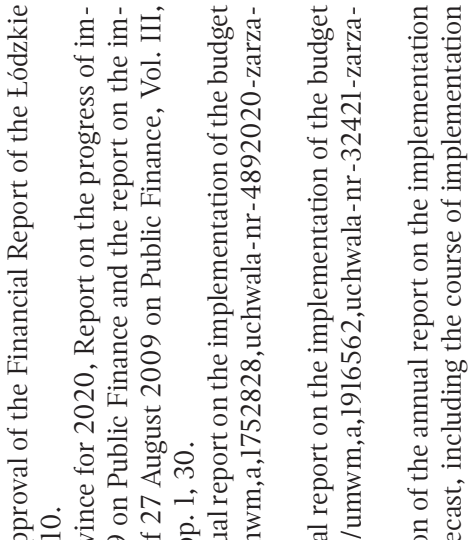
సิ

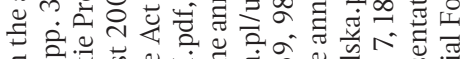
亏

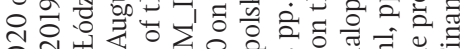

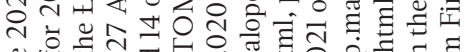
ษ 는

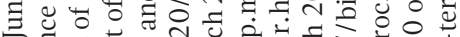

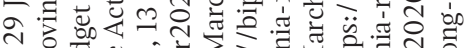

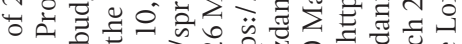

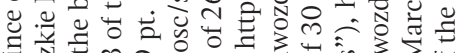

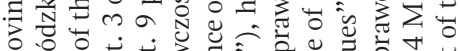

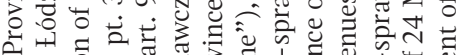
. 苟苛苛

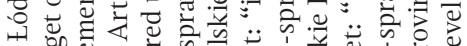

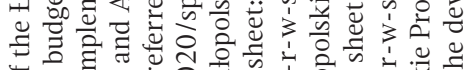
.

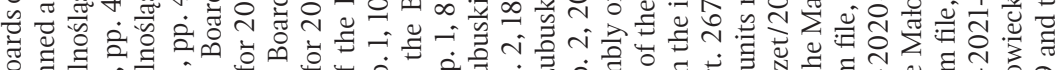

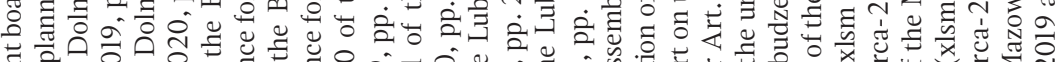

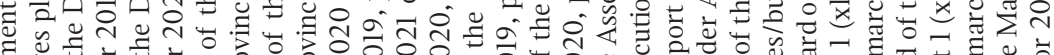
छ of 경

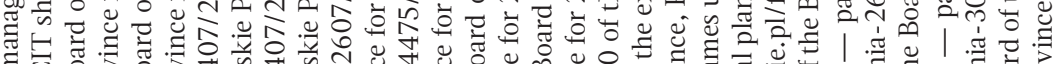

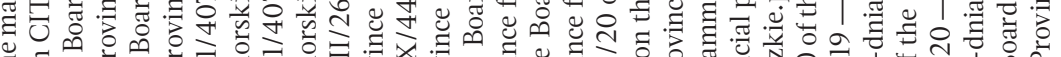

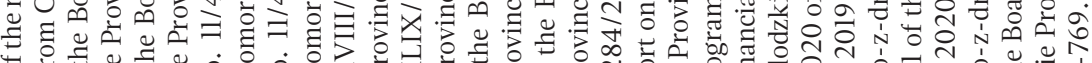

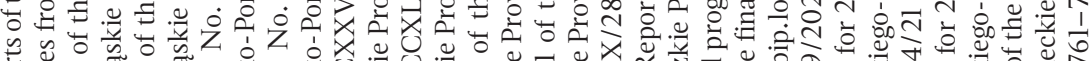

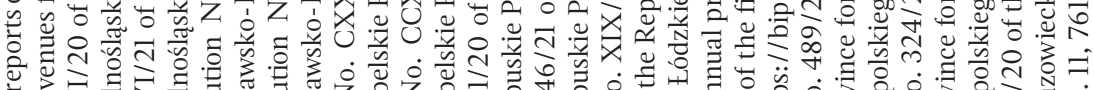

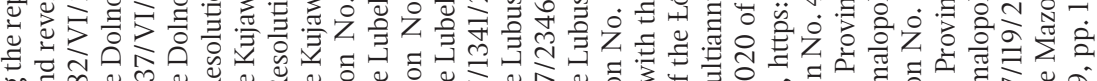

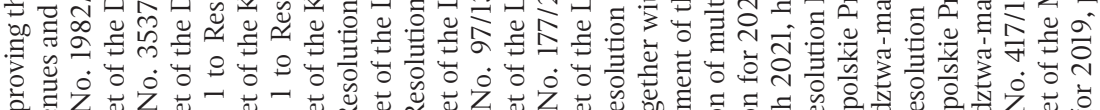

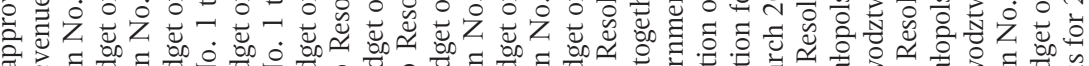

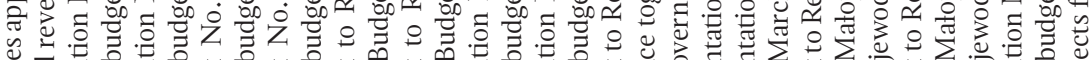

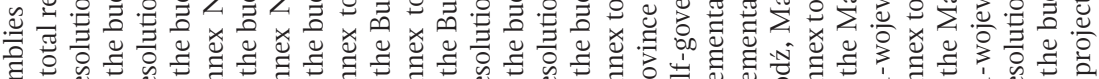

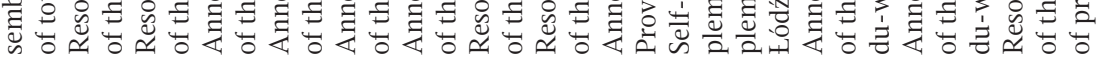




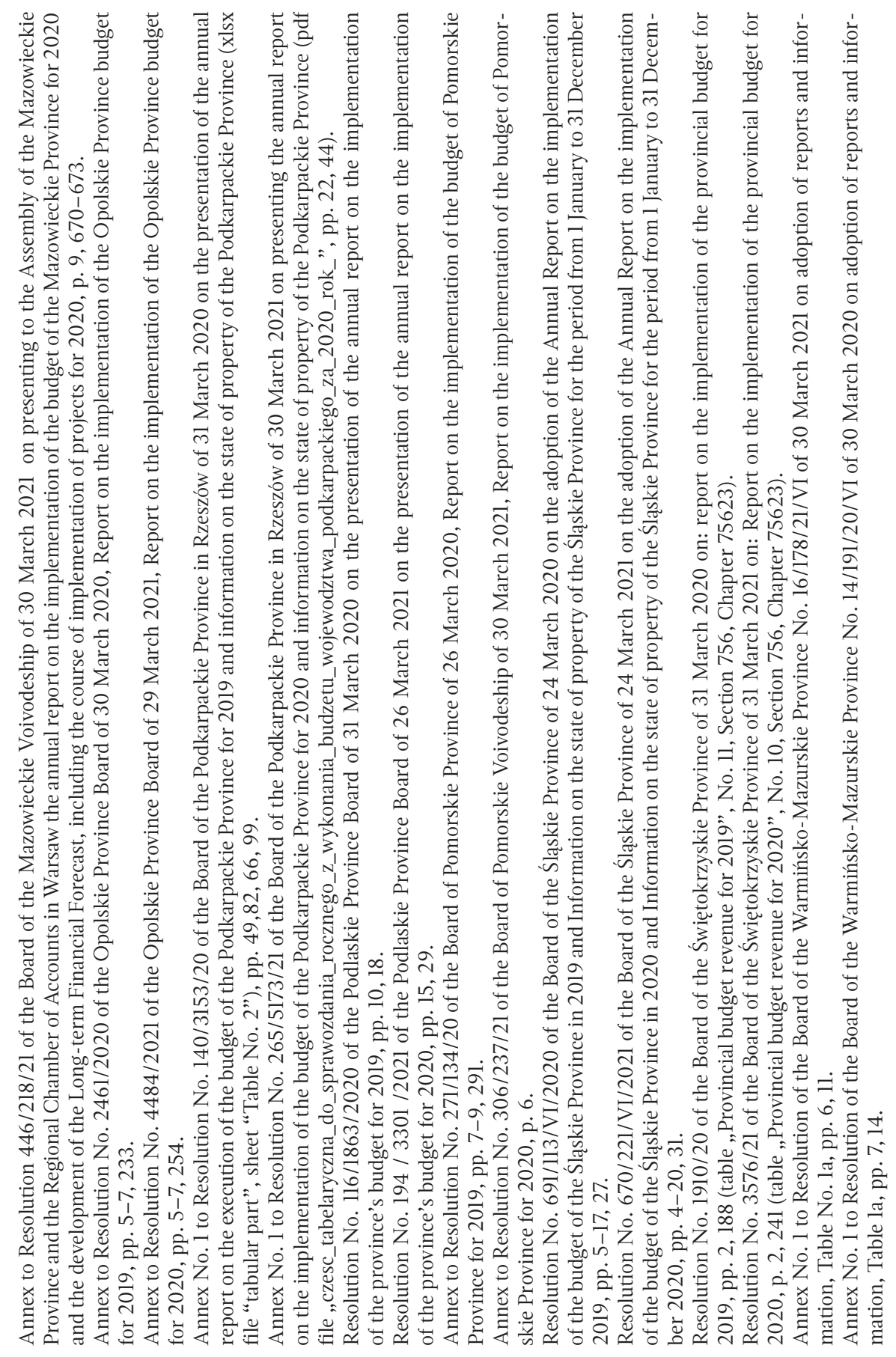




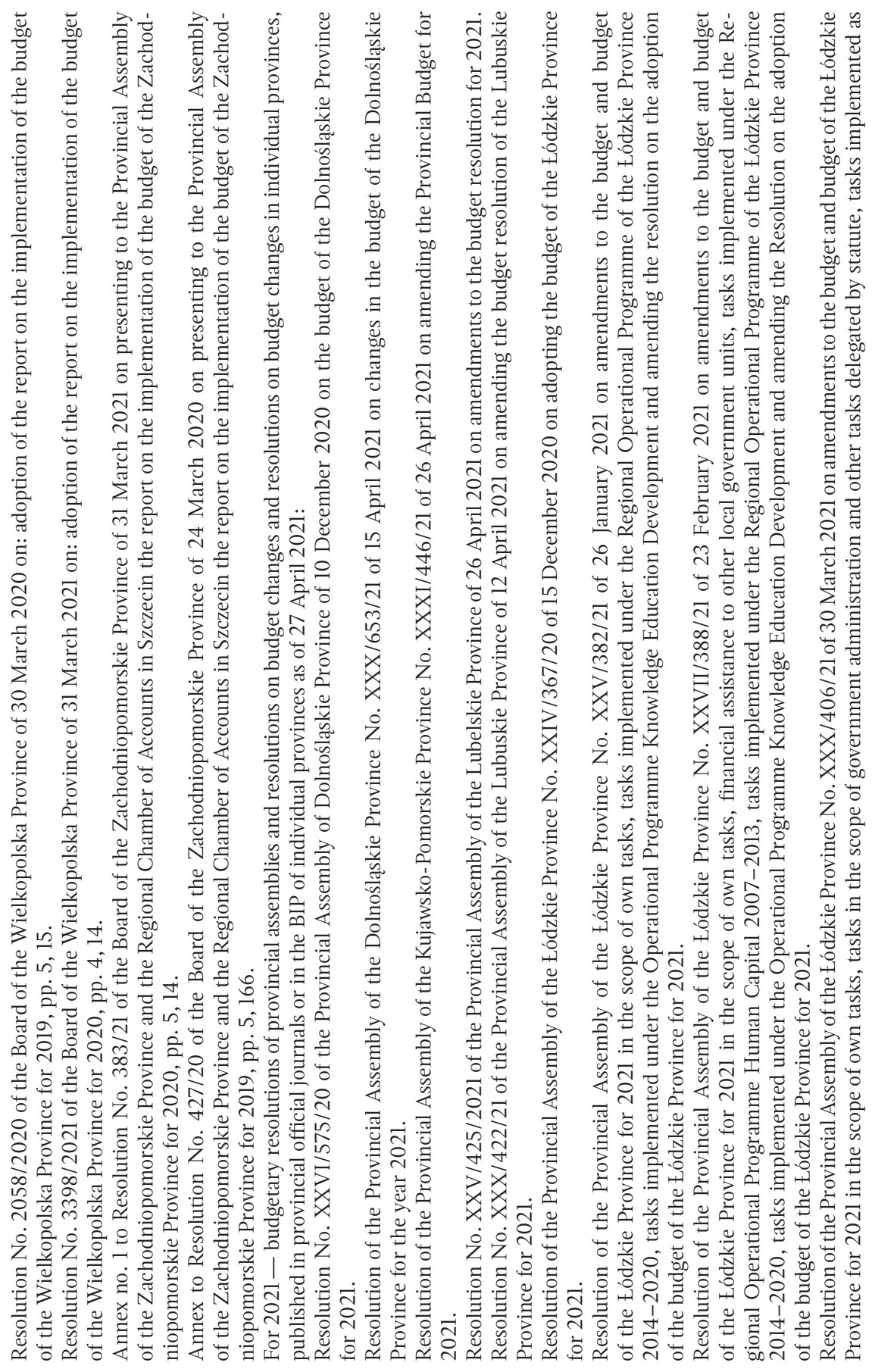




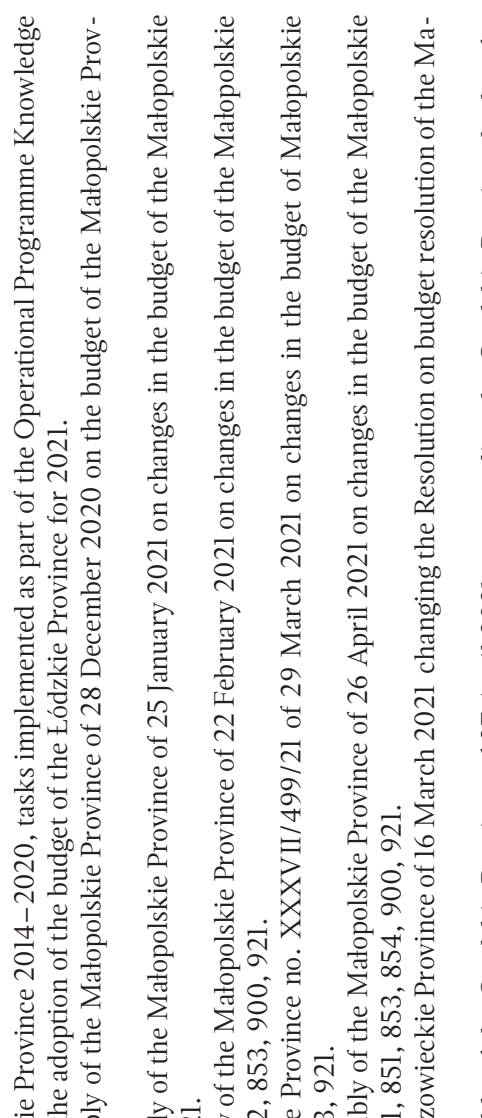

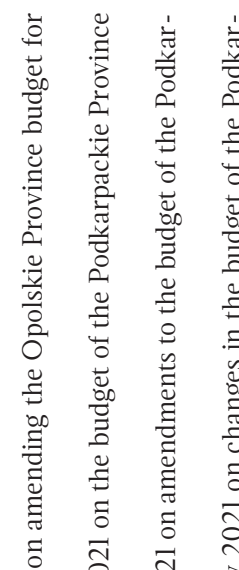

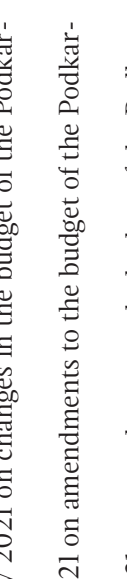

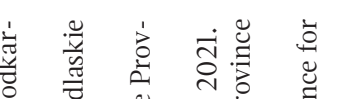
ป 穵

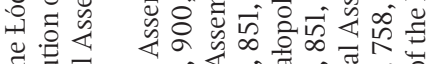

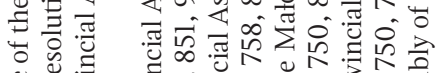

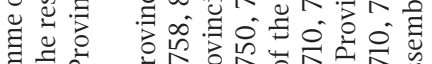

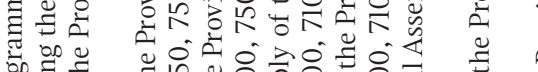
: :

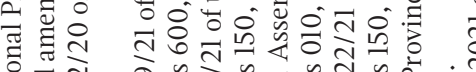

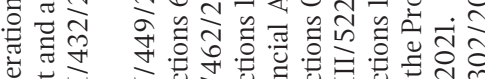

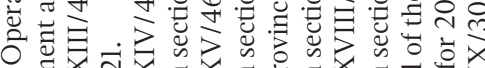

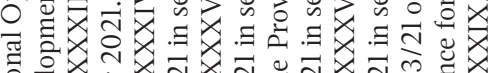

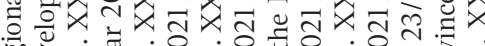

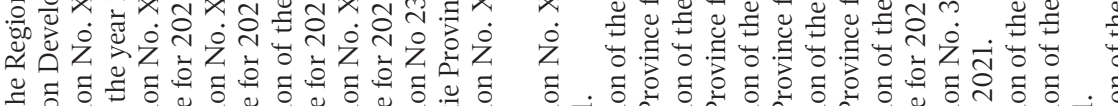

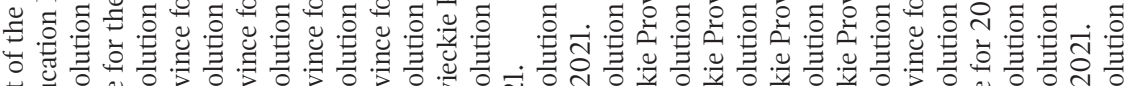

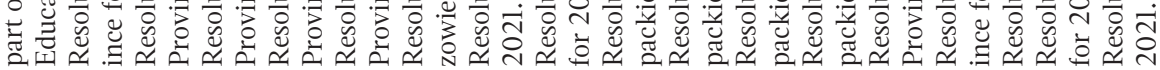




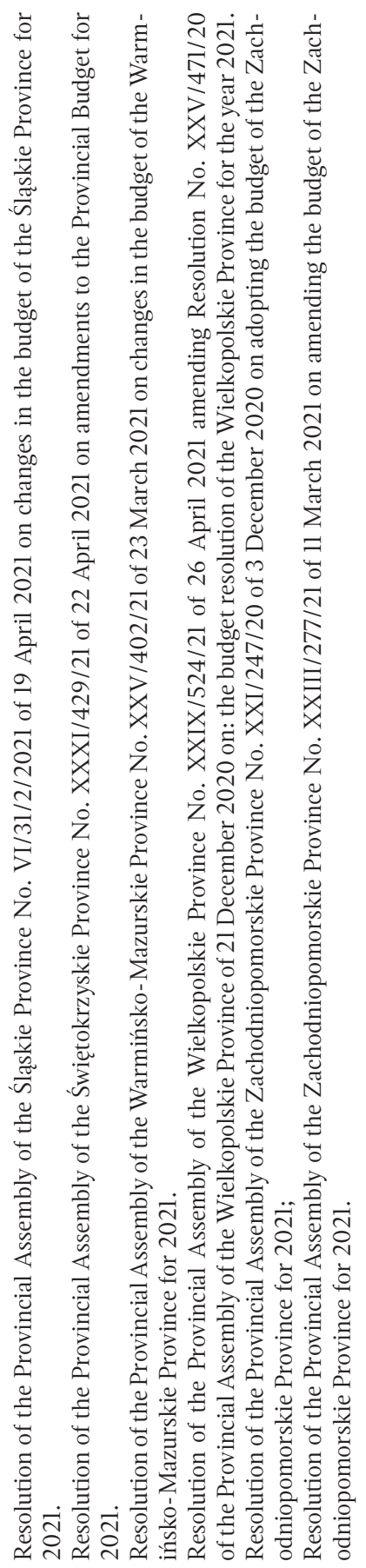

